\title{
Activation of Protein Kinase A Acutely Inhibits and Phosphorylates $\mathrm{Na} / \mathrm{H}$ Exchanger NHE-3
}

Orson W. Moe, Morimasa Amemiya, and Yasuyoshi Yamaji

Department of Internal Medicine, Department of Veterans Affairs and University of Texas Southwestern Medical Centers, Dallas, Texas 75225

\begin{abstract}
In the mammalian renal proximal tubule, protein kinase A (PKA) plays an important role in mediating hormonal regulation of apical membrane $\mathrm{Na} / \mathrm{H}$ exchanger activity. This exchanger is likely encoded by NHE-3. The present studies examined regulation of NHE-3 by PKA. NHE-3 was stably expressed in $\mathrm{Na} / \mathrm{H}$ exchanger-deficient fibroblasts (AP-1/NHE-3 cells). PKA activation (0.1 mM 8-BrcAMP $\times 20$ min) inhibited NHE-3 activity by $39 \%(P<0.01)$ with no change in NHE-3 protein abundance in the plasma membrane. To define the structural requirements for PKAmediated inhibition, full-length NHE-3 and a cytoplasmic domain-truncated mutant $\left(\mathrm{NHE}-3_{\Delta \mathrm{cyto}}\right)$ were expressed in Xenopus laevis oocytes. 8-BrcAMP inhibited NHE-3 activity by $27 \%(P<0.05)$, an effect that was blocked by $10^{-7}$ M PKA inhibitor peptide. NHE-3 $3_{\Delta \text { cyto }}$ had baseline activity similar to that of full-length NHE-3 but its activity was not regulated by 8-BrcAMP. The purified recombinant cytoplasmic domain of NHE-3 was phosphorylated in vitro by the catalytic subunit of PKA on serine residues. In AP-1/ NHE-3 cells, NHE-3 was immunoprecipitated as a $\sim$ 87-kD phosphoprotein. Addition of 0.1 mM 8-BrcAMP increased the phosphocontent of NHE-3 by threefold. In summary, acute activation of PKA inhibits NHE-3 activity, an effect that is likely mediated by phosphorylation of its cytoplasmic domain. (J. Clin. Invest. 1995. 96:2187-2194.) Key words: Na transport • hydrogen ion transport • hormonal regulation
\end{abstract}

\section{Introduction}

In eukaryotic cells, $\mathrm{Na} / \mathrm{H}$ exchangers are ubiquitous plasma membrane proteins that use inwardly directed $\mathrm{Na}$ gradients to

This work was presented in abstract form at the American Society of Nephrology meeting in Orlando, FL on 29 October 1994.

Address correspondence to Orson W. Moe, Department of Internal Medicine, University of Texas Southwestern Medical Center, 5323 Harry Hines Blvd., Dallas, TX 75235-8856. Phone: 214-648-3152; FAX: 214-648-9100. Morimasa Amemiya's present address is Jichi Medical School, Department of Nephrology, Yakushiji 3311-1, Minamikawachi, Tochiji 32944, Japan. Yasuyoshi Yamaji's present address is Keio University, Department of Medicine, 35 Shinanomachi, Shijukuku, Tokyo 160, Japan.

Received for publication 17 May 1995 and accepted in revised form 31 July 1995

J. Clin. Invest.

(c) The American Society for Clinical Investigation, Inc. 0021-9738/95/11/2187/08 $\$ 2.00$

Volume 96, November 1995, 2187-2194 extrude protons in a 1:1 stoichiometry (1-3). $\mathrm{Na} / \mathrm{H}$ exchangers perform a variety of cell functions including cell volume regulation, cell $\mathrm{pH}$ defense, and transmembrane signal transduction (1-3). In transporting epithelia, apical membrane $\mathrm{Na} / \mathrm{H}$ exchangers are critical for mediating transepithelial $\mathrm{Na}$ and $\mathrm{H}-$ equivalent transport $(1,2)$. These diverse cellular functions are served by different members of the $\mathrm{Na} / \mathrm{H}$ exchanger multi-gene family. To date, five distinct molecular isoforms (NHE-1 to 5) have been cloned (4-10). Of the five members, the most likely candidate for the epithelial apical membrane $\mathrm{Na} / \mathrm{H}$ exchanger is NHE-3, although other isoforms may also play a role. The presumption of a major role of NHE-3 is based on inhibitor pharmacokinetics $(11,12)$, transcript distribution $(7,8)$, ontogenic pattern (13), regulation by glucocorticoids $(14,15)$, and immunohistochemistry $(16,17)$.

Hormonal regulation of $\mathrm{NaCl}$ and $\mathrm{NaHCO}_{3}$ transport in renal and gastrointestinal epithelia is mediated at least in part via modulation of apical membrane $\mathrm{Na} / \mathrm{H}$ exchanger activity (13 ). In the mammalian renal proximal tubule, a number of hormones that regulate transepithelial $\mathrm{NaCl}$ and $\mathrm{NaHCO}_{3}$ transport alter cellular cyclic adenosine monophosphate (cAMP) levels (18-20). Maneuvers that increase cAMP levels have been shown to acutely decrease $\mathrm{Na} / \mathrm{H}$ exchange activity in renal cortical apical membrane vesicles $(21,22)$ and in cultured proximal tubule cell lines (23-25). The present studies demonstrate that acute protein kinase A (PKA) ${ }^{1}$ activation inhibits the activity and induces the phosphorylation of NHE-3.

\section{Methods}

Generation and culture of stable NHE-3-expressing cell lines (AP-1) NHE-3 cells). Na/H exchanger-deficient Chinese hamster ovary AP1 cells (gift from Dr. Sergio Grinstein, Toronto, Canada) (26) were maintained in Eagle $\alpha$-modified complete minimum essential medium (Sigma Immunochemicals, St. Louis, MO) supplemented with $10 \%$ fetal bovine serum (Gibco, Grand Island, NY), $100 \mathrm{U} / \mathrm{ml}$ penicillin, and $100 \mu \mathrm{g} / \mathrm{ml}$ streptomycin. Full-length rat NHE-3 cDNA (nucleotides 50-4980) (provided by Dr. John Orlowski, Montreal, Canada and Dr. Gary Shull, Cincinnati, OH) (7) was cloned into the mammalian expression plasmid pCMV-5 (gift from Dr. David Russell, Dallas, TX). AP1 cells were cotransfected by $\mathrm{CaPO}_{4}$ coprecipitation (27) with the NHE3 -expressing plasmid ( $15 \mu \mathrm{g} / 100$-mm dish) along with Ch1 $10 / \beta$-gal $(6 \mu \mathrm{g} / 100-\mathrm{mm}$ dish $)$ to monitor transfection efficiency and $\mathrm{pSV} 40 /$ neo $(6 \mu \mathrm{g} / 100-\mathrm{mm}$ dish) to provide a selectable marker (AP-1/NHE-3 cells). Cells treated in an identical fashion except that the pCMV5 expression vector did not bear the NHE-3 insert were used as controls (AP-1/pCMV5 cells). Transfectants were selected with $400 \mu \mathrm{g} / \mathrm{ml}$ G418 (Gibco) $48 \mathrm{~h}$ after transfection and neo ${ }^{+}$survivors were maintained in $200 \mu \mathrm{g} / \mathrm{ml} \mathrm{G} 418.2 \mathrm{wk}$ after transfection, neo $^{+}$cells were

1. Abbreviations used in this paper: $\mathrm{CSU}$, catalytic subunit; $\mathrm{MBP}$, maltose-binding protein; PKA, protein kinase A; RSU, regulatory subunit. 
enriched for a neo ${ }^{+} / \mathrm{NHE}-3^{+}$phenotype by acid selection as described by Franchi et al. (28). Acid selection was repeated every 2-3 d for 2 wk. Transfectants selected in this fashion showed much higher and more consistent $\mathrm{Na} / \mathrm{H}$ exchange activity compared with $\mathrm{G} 418$ selection alone. An identical round of acid selection was repeated every 3-4 mo. Clones of AP-1/NHE-3 cells were obtained by limiting dilution on 96-well plates. Studies were performed with single clones as well as pooled stable transfectants. G418 was removed from medium 1 wk and serum was removed $48 \mathrm{~h}$ before all experiments. PKA was acutely activated by incubating cells with $0.1-0.2 \mathrm{mM}$ 8-BrcAMP or chloro-phenyl-thiocAMP for the stated period of time.

Measurement of NHE-3 mRNA, immunoreactive protein, and activity in cultured cells. Poly (A) ${ }^{+}$RNA was harvested from monolayers by guanidium thiocyanate/phenol chloroform extraction and oligo-dT chromatography, size-fractionated with formaldehyde gel electrophoresis, and transferred to nylon membranes. NHE isoform-specific transcripts were detected by hybridization to uniformly ${ }^{32} \mathrm{P}$-labeled cDNAs (NHE-1, 1.9-kb BamH1 fragment; NHE-2, 1.85-kb AvaI fragment; NHE-3, 1.2-kb PstI fragment; NHE-4, 0.2-kb Nsil-BspE1 and 0.63-kb BspE1 fragments) $(4,7)$. Three antisera were used for immunoblots. Antiserum \#1314 was directed against a chimeric protein composed of maltose-binding protein (MBP) fused to the whole cytoplasmic domain

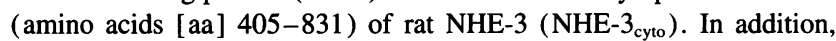
antipeptide antisera were generated to YSRHELTPNEDEKQ (aa 633646; antiserum \#1566) and DSFLQADGPEEQLQ (aa 822-835; antiserum \#1568) (7). For immunodetection of NHE-3, cells were lysed in membrane buffer: (mM: $150 \mathrm{NaCl}, 50$ Tris, $\mathrm{pH} 7.5,5$ EDTA; $\mu \mathrm{g} / \mathrm{ml}$ : 100 PMSF, 4 aprotinin, 4 leupeptin) at $4^{\circ} \mathrm{C}$ by Dounce homogenization. To obtain the plasma membrane fraction, whole cell lysate was centrifuged at 55,000 $\mathrm{g}$ (Beckman TLX: TLA100.3 rotor, 35,000 rpm, 15 min, $2^{\circ} \mathrm{C}$; Beckman Instruments, Inc., Fullerton, CA ). Membrane pellets were reconstituted in SDS buffer (1\% [wt/vol] SDS, 2\% [vol/vol] 2mercaptoethanol, 20\% [vol/vol] glycerol), size-fractionated by SDS PAGE, and transferred to nitrocellulose filters. Filters were sequentially incubated with the primary antibody (1:500 to 1:750) and peroxidasecoupled goat anti-rabbit secondary antibody $(1: 2,000)$. Labeling was detected by enhanced chemiluminescence (Amersham, Arlington Heights, IL). NHE-3 activity was measured with BCECF fluorescence as $\mathrm{Na}$-dependent intracellular $\mathrm{pH}$ recovery after acid loading with the $\mathrm{K} / \mathrm{H}$ ionophore nigericin (29). Calibration and buffer capacities were performed exactly as described previously (29). Statistical significance was established by the unpaired $t$ test.

Expression in Xenopus oocytes. Oocytes dissected from Xenopus laevis (Nasco, Fort Atkinson, WI) were defollicularized with collagenase D ( $2 \mathrm{mg} / \mathrm{ml})$ (Boehringer Mannheim Corp., Indianapolis, IN) in ORII (mM: $82.5 \mathrm{NaCl}, 2 \mathrm{KCl}, 1 \mathrm{MgCl}_{2}, 10 \mathrm{Hepes} /$ Tris, $\mathrm{pH} 7.5$ ) and stored in modified Barth's solution (mM: $88 \mathrm{NaCl}, 1 \mathrm{KCl}, 0.82 \mathrm{MgSO}_{4}$ $0.41 \mathrm{CaCl}_{2}, 0.33 \mathrm{Ca}\left(\mathrm{NO}_{3}\right)_{2}, 2.4 \mathrm{NaHCO}_{3}, 10 \mathrm{Hepes} / \mathrm{Tris}, \mathrm{pH} 7.40$, gentamicin $20 \mu \mathrm{g} / \mathrm{ml}$ ) at $18^{\circ} \mathrm{C}$. Rat NHE-3 was subcloned into the plasmid pBluescript and linear DNA templates were used for in vitro transcription of NHE-3 cRNA. An AvrI linearization yielded a transcript encoding an 831-aa full-length protein, whereas an XhoI linearization yielded a transcript encoding a 474-aa protein representing a $90 \%$ truncation of the cytoplasmic domain NHE- $3_{\Delta \text { cyto }}$. Oocytes were injected (Drummond microinjector, Broomall, PA) with $50 \mathrm{nl}$ of water with or without cRNA ( $5 \mathrm{ng} /$ oocyte for 831-aa transcript; $3.2 \mathrm{ng} /$ oocyte for 474-aa transcript). Injected oocytes were incubated in Barth's solution at $18^{\circ} \mathrm{C}$ for 3-4 $\mathrm{d}$ and viable oocytes were used for studies. Endogenous PKA was activated by incubation of oocytes in $0.1 \mathrm{mM} 8$-BrcAMP for $20 \mathrm{~min}$ before and during flux measurements. For studies with PKA inhibitor peptide, $20 \mathrm{nl}$ of a $2.5 \mu \mathrm{M}$ solution of the peptide TYADFIASGRTGRRNAI was injected into oocytes $4-6 \mathrm{~h}$ before activation of PKA.

For timed ${ }^{22} \mathrm{Na}$ uptake, oocytes were incubated in a Na-free solution (mM: 100 choline $\mathrm{Cl}, 2 \mathrm{KCl}, 1 \mathrm{CaCl}_{2}, 1 \mathrm{MgCl}_{2}, 10 \mathrm{Hepes} / \mathrm{Tris}, \mathrm{pH}$ 6.8 ) at $18^{\circ} \mathrm{C}$ for $30 \mathrm{~min}$ and uptake was initiated by transferring the oocytes to the uptake solution (mM: 99 choline $\mathrm{Cl}, 1{ }^{22} \mathrm{NaCl}[50 \mu \mathrm{Ci}$ / $\mathrm{ml}$ ], $2 \mathrm{KCl}, 1 \mathrm{CaCl}_{2}, 1 \mathrm{MgCl}_{2}, 10 \mathrm{Hepes} / \mathrm{Tris}, \mathrm{pH} 7.4$ ) for $30 \mathrm{~min}$ at $18^{\circ} \mathrm{C}$. Transport was terminated by adding an excess volume of ice-cold stop solution ( $\mathrm{mM}$ : 50 choline $\mathrm{Cl}, 50 \mathrm{NaCl}, 2 \mathrm{KCl}, 1 \mathrm{CaCl}_{2}, 1 \mathrm{MgCl}_{2}$, 10 Hepes/Tris, $\mathrm{pH} 7.4$ ). Individual oocytes were lysed with $10 \%$ SDS and uptakes were determined by scintillation counting. Each data point was the mean of 15-20 oocytes. Statistical significance was established by the $t$ test.

In vitro phosphorylation and phosphoamino acid analysis. Rat NHE- $3_{\text {cyto }}$ was cloned into the isopropylthio- $\beta$-D-galactoside (IPTG) inducible bacterial expression vector pMAL-c2 (New England Biolab, Beverly, MA) $3^{\prime}$ to and in frame with the coding sequence of MBP. After transformation into Escherichia coli, the MBP/NHE- $3_{\text {cyto }}$ fusion protein was induced by $0.3 \mathrm{mM}$ IPTG at $20^{\circ} \mathrm{C}$ and purified by amylose column chromatography. Two bands were consistently seen on Coomassie-stained gels from different preparations representing the full-length MBP/NHE- $3_{\text {cyto }}$ fusion protein plus a truncated product (see Results).

In vitro phosphorylation was performed by incubating $100 \mathrm{ng}$ of the fusion protein in a buffer containing $(\mathrm{mM}): 50$ Hepes/Tris, $\mathrm{pH} 7.0,3$ DTT, $5 \mathrm{MgCl}_{2}$, 1 EGTA, 0.1 ATP, $30 \mu \mathrm{Ci}\left[\gamma^{-32} \mathrm{P}\right] \mathrm{ATP}, 25 \mathrm{U}$ of the catalytic subunit of PKA (PKA-CSU), and equimolar amount of the regulatory subunit of PKA (PKA-RSU). Reaction was initiated by addition of $75 \mu \mathrm{M}$ cAMP. Phosphorylation was terminated at the indicated times by taking aliquots from the reaction and boiling the sample in SDS buffer. ${ }^{32} \mathrm{P}$-labeled phosphoproteins were resolved by SDS-PAGE, dried, and exposed to film.

Phosphoamino acids were analyzed by two-dimensional electrophoresis (30). The ${ }^{32} \mathrm{P}$-labeled phosphoprotein was eluted from dried polyacrylamide with $50 \mathrm{mM} \mathrm{NH} \mathrm{HCO}_{3}$, TCA-precipitated, and hydrolyzed by boiling in $6 \mathrm{M} \mathrm{HCl} .{ }^{32} \mathrm{P}$-labeled phosphoamino acids along with standards (P-Ser, P-Thr, P-Tyr) were spotted on TLC plates and electrophoretically resolved (first dimension: $2.2 \%$ formic acid, $7.8 \%$ acetic acid, $\mathrm{pH} 1.9$; second dimension: $5 \%$ acetic acid, $0.5 \%$ pyridine, $\mathrm{pH}$ 3.5) with a Hunter thin layer electrophoresis unit (HTLE-7000: CBS Scientific, Del Mar, CA). Phosphoamino acids were detected by autoradiography and identified by alignment with ninhydrin-stained standards.

Immunoprecipitation and in vivo phosphorylation. For experiments characterizing the immunoprecipitation, AP-1/NHE-3 cells were solubilized with RIPA buffer (containing [mM]: $150 \mathrm{NaCl}, 80 \mathrm{NaF}, 50$ Tris$\mathrm{HCl}, \mathrm{pH}$ 8.0, 5 EDTA, 1 EGTA, $25 \mathrm{Na}$ pyrophosphate, $1 \mathrm{Na}$ orthovanadate; NP-40 1.0\% [ $\mathrm{vol} / \mathrm{vol}$ ], deoxycholate $0.5 \%$ [wt/vol], SDS $0.1 \%$ [wt/vol] ) at $4^{\circ} \mathrm{C}$ and the solubilized proteins were separated from the membranes as a 100,000 $g$ supernatant (Beckman TLX: TLA100.3 rotor, $55,000 \mathrm{rpm}, 30 \mathrm{~min}, 2^{\circ} \mathrm{C}$ ). After preclearing with normal rabbit serum and protein A-Sepharose, polyclonal anti-NHE-3 fusion protein antibody (\#1314) was added at a 1:500 dilution and the mixture was incubated for $1 \mathrm{~h}$ at $4^{\circ} \mathrm{C}$. The $\mathrm{Ag}-\mathrm{Ab}$ complex was precipitated by incubation with protein A-Sepharose, washed with RIPA buffer, eluted with SDS buffer, resolved on SDS-PAGE, and electrotransferred to nitrocellulose membranes. The identity of the precipitated protein was checked by immunoblots using anti-fusion protein antisera \#1314, or antipeptide antisera \#1565 or \#1568. To examine the specificity of labeling by antisera \#1565 and \#1568, $50 \mu \mathrm{g} / \mathrm{ml}$ of the appropriate immunogenic peptide was preincubated with the antisera before labeling of the nitrocellulose membranes. To examine the specificity of the immunoprecipitation, the immunoprecipitating antisera \#1314 was first saturated with $1 \mu \mathrm{g} / \mathrm{ml}$ of the purified bacterial fusion protein before exposure to solubilized AP-1/NHE-3 membranes containing the mammalian-expressed NHE-3.

To quantify in vivo phosphorylation of NHE-3, AP-1/NHE-3 cells were phosphate-depleted in nominally phosphate-free medium for $1 \mathrm{~h}$ at $37^{\circ} \mathrm{C}$ and then labeled with phosphate-free medium containing 330 $\mu \mathrm{Ci} / \mathrm{ml}{ }^{32} \mathrm{P}$-orthophosphate for $3 \mathrm{~h}$. After PKA activation with $0.1 \mathrm{mM}$ 8-BrcAMP, cells were cooled to $4^{\circ} \mathrm{C}$ and NHE-3 was immunoprecipitated and size-fractionated as described above. The ${ }^{32} \mathrm{P}$-content of NHE3 was quantified by overnight autoradiography. The amount of NHE3 protein was subsequently determined by immunoblotting the same nitrocellulose membranes with anti-NHE-3 antibody as described 


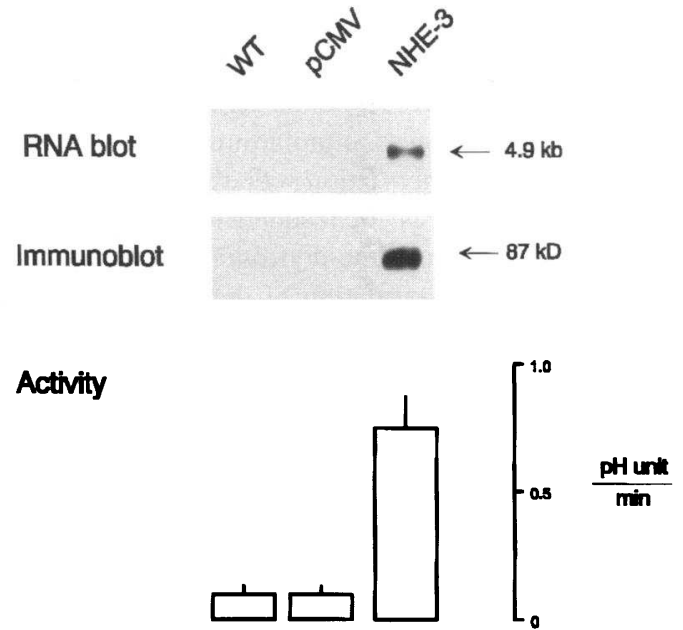

Figure 1. Characterization of AP-1/NHE-3 cells. NHE-3 expression was studied in AP-1 cells stably transfected with the rat NHE-3 cDNA (NHE-3) and compared with wild-type AP-1 cells (WT) and control cells transfected with only pCMV5 and the neo selection marker gene $(p C M V)$. Typical RNA blot [5 $\mu \mathrm{g}$ poly $(\mathrm{A})^{+} \mathrm{RNA} /$ lane ], immunoblot $(20 \mu \mathrm{g} /$ lane $)$, and fluorometric functional assay (Na-dependent cell alkalinization after acid load) of NHE-3 activity are shown for the three cell types.

above. Changes in phosphorylation status were expressed as changes in the ${ }^{32} \mathrm{P}$ signal normalized to the antigenic signal.

\section{Results}

AP-1 cells: NHE-3 activity is inhibited by acute activation of $P K A$. We first examined the effect of PKA on NHE-3 in mammalian cells. To secure that the reconstituted $\mathrm{Na} / \mathrm{H}$ exchanger ${ }^{+}$ phenotype was indeed due to NHE-3 expression, we showed that NHE-3 mRNA, protein, and $\mathrm{Na} / \mathrm{H}$ exchange activity was expressed only in the AP-1/NHE-3 cells and not in the wildtype AP-1 or AP-1/pCMV5 controls (Fig. 1). RNA blots of AP-1/NHE-3 cells for NHE-1, 2, and 4 transcripts were negative (data not shown).

Fig. 2 shows the effect of PKA activation on NHE-3 activity in pooled AP-1/NHE-3 cells. When these cells were incubated with 8-BrcAMP for $20 \mathrm{~min}$, NHE-3 activity was inhibited by

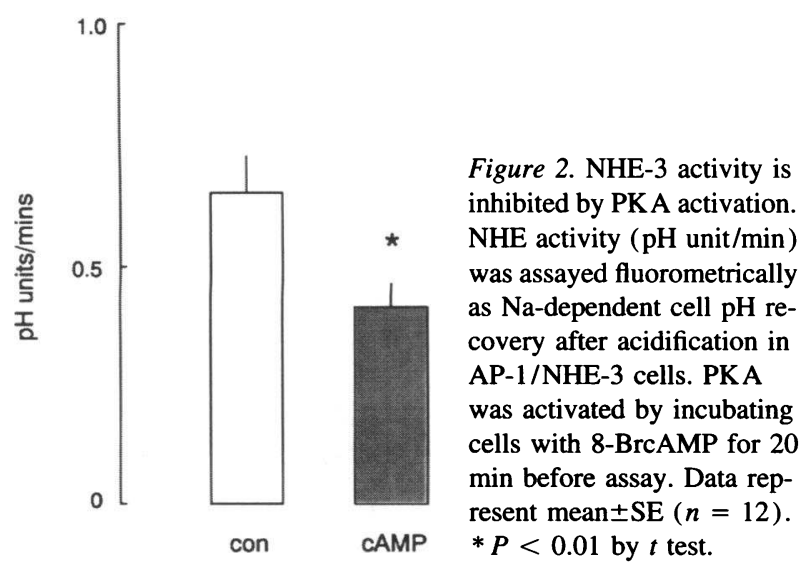

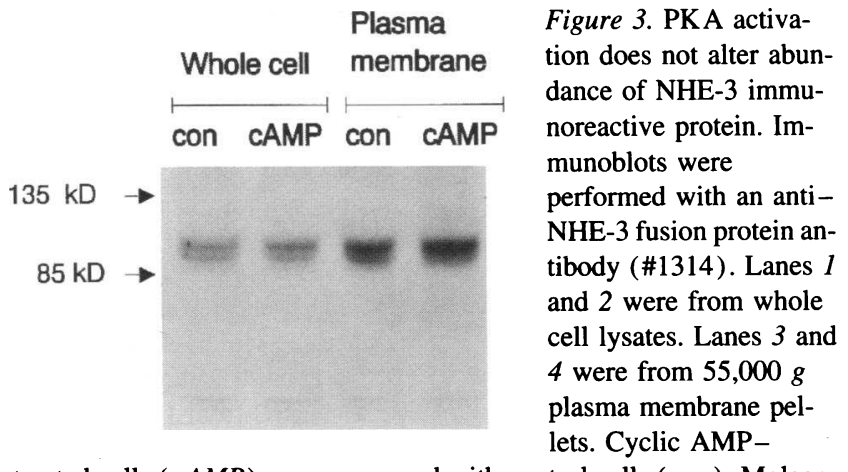

treated cells ( $C A M P)$ were compared with control cells (con). Molecular mass standards are shown on the left. Three independent experiments showed similar results.

39\% (control: $0.65 \pm 0.05 \mathrm{pH} \mathrm{U} / \mathrm{min}$, cAMP: $0.40 \pm 0.03 \mathrm{pH} \mathrm{U} /$ $\min , n=12, P<0.01)$ 8-BrcAMP had no effect on buffer capacity (control: $20.0 \pm 2.9 \mathrm{mM} / \mathrm{pH} \mathrm{U}$, cAMP $18.9 \pm 3.4 \mathrm{mM} /$ $\mathrm{pH} \mathrm{U}, n=4$, NS), resting cell pH (control: $7.45 \pm 0.06$ vs. cAMP: $7.41 \pm 0.08, n=10, \mathrm{NS}$ ), or the trough $\mathrm{pH}$ before $\mathrm{Na}$ addition (control: $6.80 \pm 0.09$ vs. cAMP: $6.77 \pm 0.08, n=10$, NS). Fig. 3 shows that this change in activity was not associated with changes in NHE-3 protein abundance in whole cell lysate or plasma membrane fraction. These results indicate that degradation of existing NHE-3 is unlikely responsible for the inhibition. However, these findings are compatible with cAMP-induced covalent modification of NHE-3 leading to either internalization or inhibition of intrinsic transporter activity. Three clones of AP-1/NHE-3 cells were also examined for the effect of acute PKA activation on NHE-3 activity to screen for a clone with a maximal response. In all cases, NHE-3 activity was inhibited by cAMP to a similar degree $(30-45 \%$, data not shown). The remainder of the studies were performed in pooled cells.

Xenopus oocytes: inhibition of NHE-3 by acute PKA activation requires an intact cytoplasmic domain. To confirm that PKA activation inhibits NHE-3, a second expression system, Xenopus oocytes were used to examine the structural requirements for acute PKA regulation. As shown in Fig. 4, oocytes

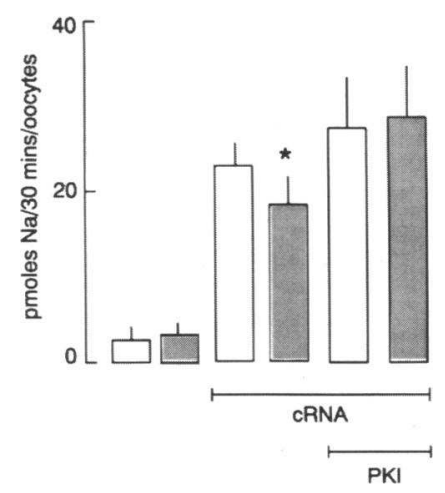

Figure 4. NHE-3 activity is inhibited by PKA. Xenopus oocytes were injected with 5 ng of full-length NHE-3 cRNA and NHE activity was measured by ${ }^{22} \mathrm{Na}$ flux $4 \mathrm{~d}$ later. Water-injected controls are shown on the left. For inhibitor studies, the inhibitor peptide (TYADFIASGRTGRRNAI) was injected into oocytes $6 \mathrm{~h}$ before the experiments were performed. PKA activation was achieved by incubation of oocytes with $0.1 \mathrm{mM} 8$ 8-BrcAMP for $20 \mathrm{~min}$ before uptake. Data points are means \pm SD from 15-20 oocytes. Cyclic AMP-treated cells (filled bars) were compared with controls (open bars). *P $<0.05$ by $t$ test. Three independent sets of experiments showed similar results. 


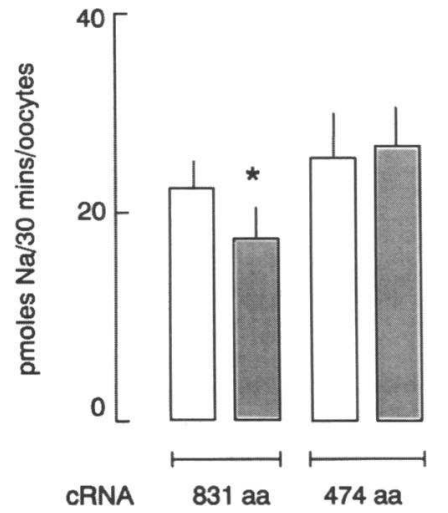

Figure 5. Inhibition of NHE3 activity by PKA requires an intact cytoplasmic domain. cRNAs representing full-length NHE-3 (831 $a a$ ) or one with a cytoplasmic truncation (NHE-3 ${ }_{\Delta \text { cyto }}$, $474 a a$ ) were injected into Xenopus oocytes and NHE3 activity was assayed as ${ }^{22} \mathrm{Na}$ uptake. Data represent means \pm SD from $15-20$ oocytes. Cyclic AMP-treated cells (filled bars) were compared with controls (open bars). $\quad * P<0.05$ by $t$ test. Three independent experiments showed similar results.

injected with the full-length NHE-3 cRNA exhibited a fivefold increase in ${ }^{22} \mathrm{Na}$ uptake compared with water-injected controls. Addition of $0.1 \mathrm{mM} 8$-BrcAMP for $20 \mathrm{~min}$ caused a $20 \%$ inhibition of ${ }^{22} \mathrm{Na}$ uptake. When oocytes were first injected with the PKA inhibitor peptide, subsequent cAMP addition did not lead to inhibition of Na uptake (Fig. 4). There was a tendency for baseline NHE-3 activity to be higher in inhibitor peptideinjected oocytes, but this finding was not consistent in every experiment.

Fig. 5 compares the activity of the full-length 831-aa NHE-3 protein with the NHE-3 $3_{\Delta \text { cyto }} 474$-aa protein. The transmembrane domain of the protein alone was sufficient to induce $\mathrm{Na}$ uptake to levels comparable with the full-length protein. However, while acute cAMP addition inhibited $\mathrm{Na}$ uptake in the fulllength transporter, the activity of the truncated protein was unaltered by cAMP addition (Fig. 5). These studies suggest that the cytoplasmic domain is necessary for PKA to exert its acute effect on NHE-3 activity.

NHE- $3_{\text {cyto }}$ is a substrate for PKA phosphorylation in vitro. A possible mechanism for the above effects is phosphorylation of the NHE-3 cytoplasmic domain by PKA. We tested this hypothesis first by examining the ability of PKA-CSU to phosphorylate the cytoplasmic domain of NHE-3 in vitro. The purified fusion protein was comprised of two bands (see Fig. 8, Coomassie blue stain). Antigenically, antiserum \#1566 (epitope: aa 633-646) recognized both bands, whereas antiserum \#1568 (epitope: aa 809-822) recognized only the faster migrating band (17). This suggests that the faster migrating band is a truncated product of the full-length protein. This result was consistent over several preparations and purifications, independent of protease inhibitors, and likely represents a product of systematic premature bacterial translational termination. When the fusion protein was exposed to equimolar amounts of PKACSU and PKA-RSU, no phosphorylation was observed over 10 min (Fig. 6). When cAMP was then added to the reaction, phosphorylation was initiated in a time-dependent manner (Fig. 6 ). To demonstrate that phosphorylation of the fusion protein occurred on the NHE- $3_{\text {cyto }}$ domain of the fusion protein and not MBP, we subjected a mixture of the MBP/NHE- $3_{\text {cyto }}$ fusion protein with pure MBP to PKA-CSU in vitro (Fig. 7). Even when the fusion protein was phosphorylated to saturation, no phosphorylation was observed on MBP alone (Fig. 7). Phosphoamino acid analysis of the phosphorylated NHE- $3_{\text {cyto }}$ revealed only phosphoserines with no detectable counts on threonine or tyrosines (negative 1-wk exposure) as one would expect for the vast majority of PKA substrates (Fig. 8) (31).

NHE-3 phosphorylation is stimulated in vivo by PKA activation. Partial denaturation of proteins in solution can expose cryptic phosphorylation sites that may not be relevant in the in vivo environment. Therefore, in vitro phosphorylation by purified PKA does not establish a priori that NHE-3 is a substrate for phosphorylation by PKA in vivo. To investigate in vivo phosphorylation, we next examined the effect of cAMP on the phosphorylation status of NHE-3 in intact cells. We documented the specificity of the immunoprecipitation of NHE-3 from AP$1 /$ NHE- 3 cells in several ways. First, the anti-fusion protein antiserum \#1314 precipitated a single $87-\mathrm{kD}$ protein which has the same mobility as NHE-3 and was labeled by the same antiserum on immunoblot (Fig. 9, lane 2). Second, preimmune serum from the same animal (Fig. 9, lanes 1, 4, and 7) or nonimmune serum from control rabbits (data not shown) did not precipitate any proteins that were recognized by any of the anti-NHE-3 antisera. Third, when the immunoprecipitating antisera 1314 was first saturated with bacterially expressed $\mathrm{MBP} / \mathrm{NHE}-3_{\text {cyto }}$ fusion protein before it was added to solubilized membrane protein from AP-1/NHE-3 cells, the only proteins bound to the immunoglobulin was the fusion protein (Fig. 9, lane 3). Incubation with MBP did not block the precipitation (data not shown). Fourth, the identity of the precipitated protein was further established antigenically by labeling with two antipeptide antisera (\#1565 and \#1568) directed against two different NHE-3 cytoplasmic epitopes (Fig. 9, lanes 5 and 8). Labeling by either antisera was blocked by preincubation with the appropriate peptide (Fig. 9, lanes 6 and 9).

We next pulsed AP-1/NHE-3 cells with ${ }^{32} \mathrm{PO}_{4}$ and examined
PKA-CSU

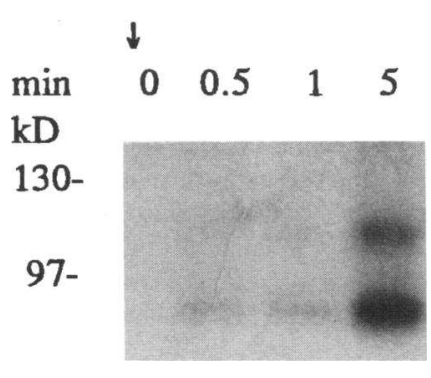

PKA-CSU

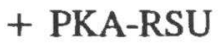

$\downarrow$

$\begin{array}{lll}0 & 0.5 & 1\end{array}$

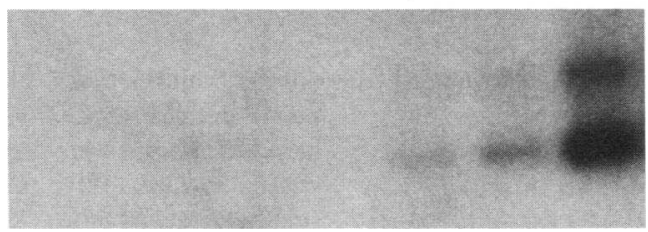

Figure 6. PKA specifically phosphorylates NHE- $3_{\text {cyto }}$ in vitro. MBP/NHE- $3_{\text {cyto }}$ fusion protein was incubated with equimolar concentrations of the catalytic subunit ( $P K A$ $C S U)$ and the regulatory subunit (PKA$R S U$ ) of PKA. Aliquots were taken at the indicated times for SDS-PAGE and autoradiography. Phosphorylation was initiated by addition of cAMP after $10 \mathrm{~min}$. Three independent experiments showed similar results. 
Figure 7. PKA phosphorylates NHE- $3_{\text {cyto }}$ and not Coomassie Autorad MBP. A mixture of MBP/ NHE- $3_{\text {cyo }}$ fusion protein and purified MBP was subjected to phosphorylation by PKACSU for $30 \mathrm{~min}$ and resolved by SDS-PAGE. The left lane shows the Coomassiestained proteins and the right lane shows the autoradiograph.

immunoprecipitated NHE-3. Control cells were compared with cells treated with permeable cAMP analogues for $20 \mathrm{~min}$. Fig. 10 shows that NHE- 3 exists as a phosphoprotein under baseline conditions in vivo and that activation of PKA increased the phosphocontent of NHE- 3 by threefold without a change in its protein abundance.

\section{Discussion}

In the renal proximal tubule, adrenergic agonists (32-34), parathyroid hormone (PTH) $(21,23,35)$, dopamine $(20,36)$, angiotensin II (37-39), and endothelin $(40,41)$ all regulate proximal tubule $\mathrm{NaCl}$ and/or $\mathrm{NaHCO}_{3}$ absorption, in part via modulation of apical membrane $\mathrm{Na} / \mathrm{H}$ exchanger activity. For hormones such as dopamine and PTH, PKA activation is presumed to play a major role in mediating inhibition of $\mathrm{Na} / \mathrm{H}$ exchanger activity $(21-23,35,42)$. Similarly, inhibition of PKA has been postulated by some to mediate $\mathrm{Na} / \mathrm{H}$ exchanger stimulation by angiotensin II (37-39) and catecholamines (3234). Although more than one NHE isoforms may be involved, current evidence (see Introduction) suggests that NHE-3 is the predominant isoform responsible for proximal tubule apical membrane $\mathrm{NaCl}$ and $\mathrm{NaHCO}_{3}$ transport. We therefore studied the effect of PKA activation on the NHE-3 isoform.

We showed functional inhibition of NHE-3 by activation of PKA in two eukaryotic expression systems. In contrast, when rabbit NHE-3 was expressed in PS120 cells, an Na/H exchanger-deficient cell line derived from Chinese hamster lung fibroblasts, cAMP addition had no effect on NHE-3 activity (43). Rabbit NHE-3 has several consensus PKA sites that are conserved with rat and opossum NHE-3 (7-9). Although both PS120 and AP-1 (Chinese hamster ovary-derived) cells are both fairly poorly differentiated cell lines, phenotypic differences between the two cell types are likely to exist and may account for the disparate results.

In Xenopus oocytes, the transmembrane domain of NHE-3 alone is sufficient to sustain Na transport. Although the cytoplasmic domain was not obligatory for $\mathrm{Na}$ transport, it was crucial for mediating the effect of PKA on NHE-3 activity. The 474-aa NHE-3 ${ }_{\Delta \text { cyto }}$ tended to have higher basal levels of $\mathrm{Na}$ uptake although this finding was not consistent in every experiment. This may reflect a variable degree of baseline PKA activity in oocytes. This modular design of respective transport and regulatory roles for the transmembrane and cytoplasmic domains has been observed in the NHE-1 isoform which shares the same predicted secondary structure with all the members of the NHE gene family (4-10). Wakabayashi et al. (44) showed

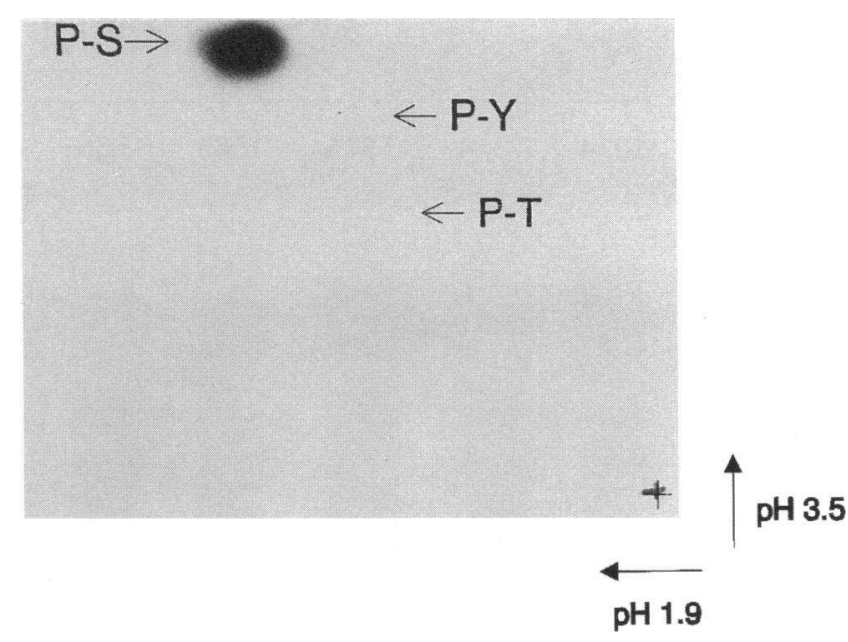

Figure 8. PKA phosphorylates NHE-3 in vitro on serine residues. MBP/ NHE- $3_{\text {cyto }}$ fusion protein was phosphorylated by PKA-CSU in vitro, digested with $\mathrm{HCl}$, and ${ }^{32} \mathrm{P}$-labeled phosphoamino acids were resolved by two-dimensional electrophoresis as described in Methods. Migration positions of phosphoamino acid standards are indicated. Three independent experiments showed similar results.

that cytoplasmic domain-truncated NHE-1 mutants retained the ability to perform $\mathrm{Na} / \mathrm{H}$ exchange but lost their ability to be regulated acutely by growth factors. Winkel et al. (45) blocked the endothelin and $\alpha$-thrombin-induced stimulation of native $\mathrm{Na} / \mathrm{H}$ exchanger activity in Chinese hamster ovary cells (likely NHE-1) by microinjecting cells with anti-NHE-1 antibodies directed against cytoplasmic domain epitopes. A piscine homologue of mammalian NHE-1 ( $\beta \mathrm{NHE}$ ) which shares the same predicted topology with the mammalian NHE family, is acutely stimulated by cAMP (46). A $\beta$ NHE mutant with two-thirds of its cytoplasmic domain truncated retained its transport function, but was no longer activated by PKA $(46,47)$. In addition, human NHE-1 which is PKA insensitive can be rendered PKAsensitive if its cytoplasmic domain is replaced by the $\beta \mathrm{NHE}$ cytoplasmic domain (48).

In the present study, differences in AP-1/NHE-3 plasma membrane NHE-3 protein abundance cannot account for the $40 \%$ inhibition of NHE- 3 activity induced by cAMP. This finding is consistent with the hypothesis of inhibition of existing NHE-3 transporters by acute phosphorylation. Alternatively, acute phosphorylation can lead to endocytosis of surface NHE3. The present data cannot definitively distinguish these two possibilities. We showed that recombinant rat NHE-3 cytoplasmic domain was a direct substrate for purified PKA in vitro. Rat NHE-3 cytoplasmic domain contains numerous putative PKA consensus motifs. Three of these sites at $\mathrm{Ser}^{575}, \mathrm{Ser}^{690}$, and $\mathrm{Ser}^{804}$ are conserved in rat, rabbit, and opossum NHE-3 (7-9). Neither the presence of consensus sequences nor direct in vitro PKA phosphorylation per se proves unequivocally that NHE-3 is a direct substrate for PKA in vivo. However, collectively they are highly suggestive of phosphorylation of NHE-3 by PKA in vivo. In the Na-K-ATPase $\alpha$ subunit, GLUT-4 glucose transporter, and CFTR, most putative PKA consensus sites are phosphorylated in vitro by purified PKA as well as in vivo by cAMP addition (49-53). We demonstrated that NHE-3 exists as a phosphoprotein and PKA activation increased its net 


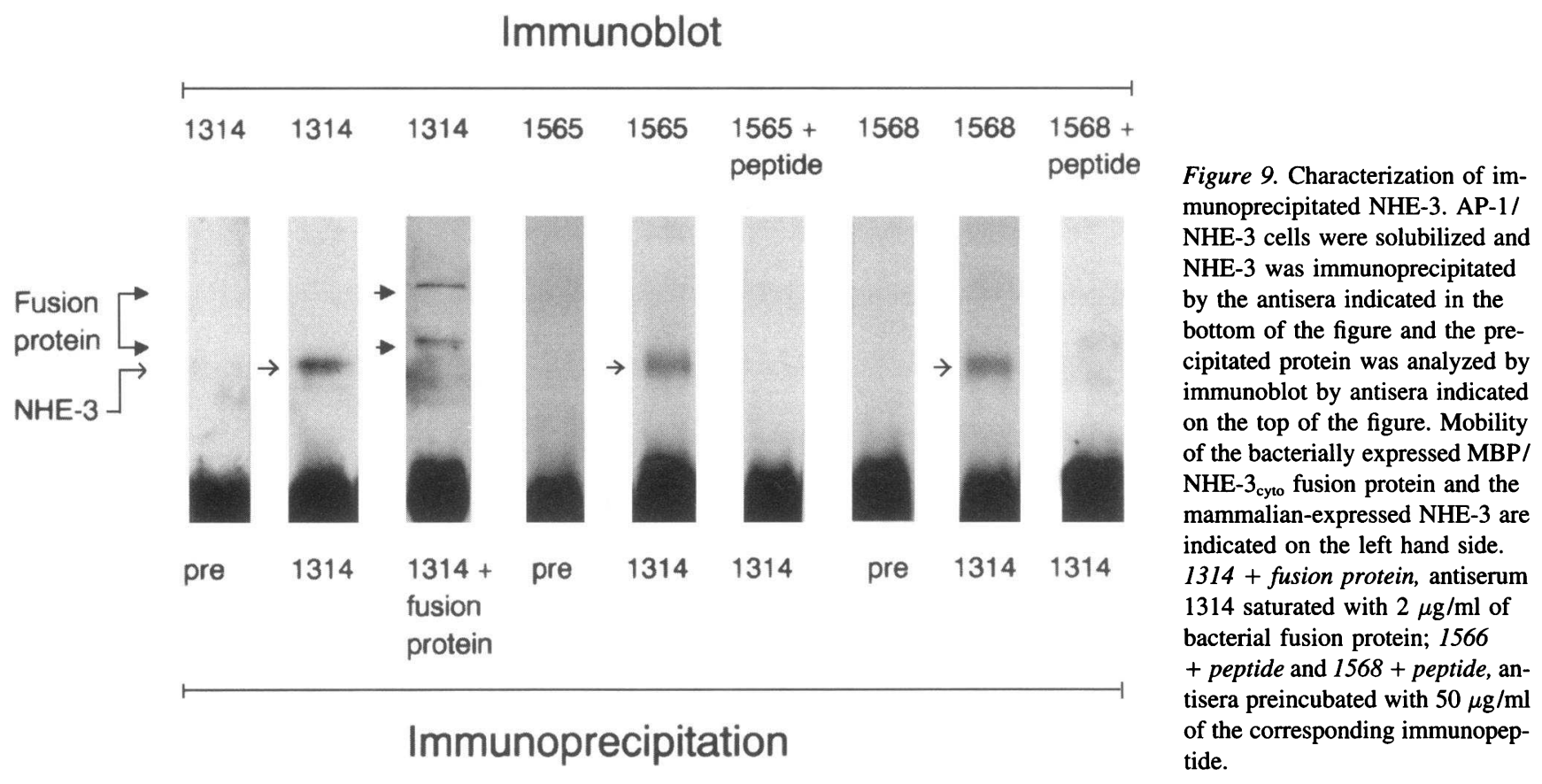

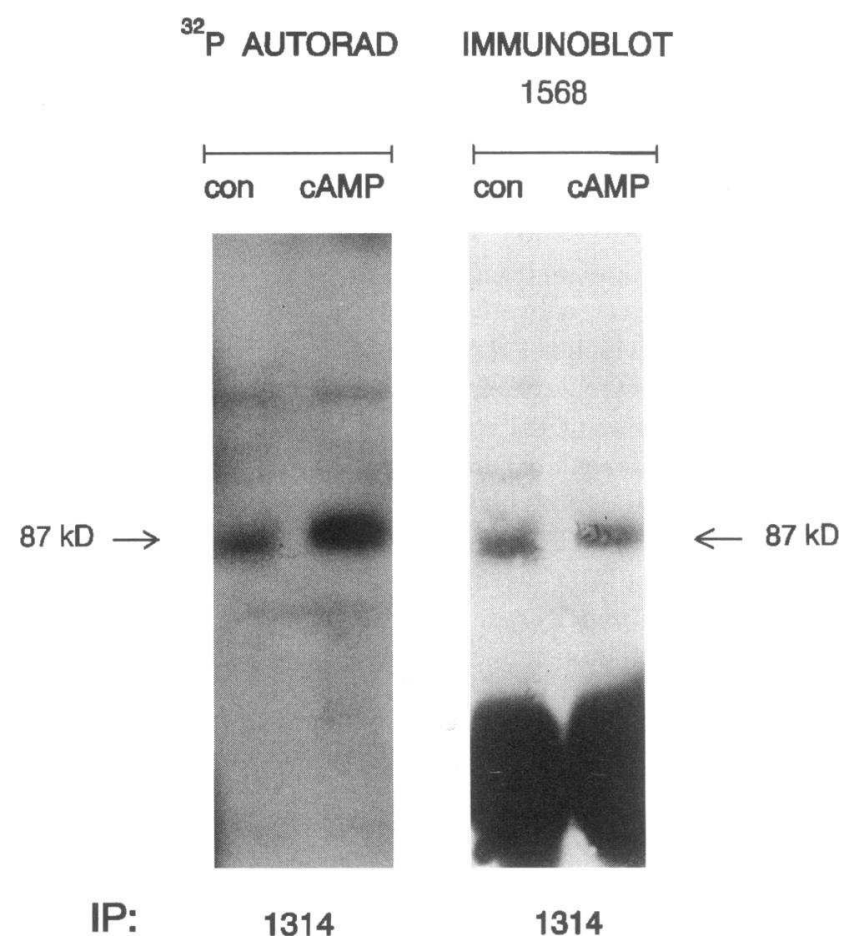

Figure 10. PKA induces NHE-3 phosphorylation in AP-1 cells. AP-1/ NHE-3 cells were labeled with ${ }^{32} \mathrm{P}$-orthophosphate and PKA was activated by $0.1 \mathrm{mM}$ 8-BrcAMP. NHE-3 was immunoprecipitated with antiserum 1314, resolved on SDS-PAGE, and blotted to nitrocellulose filters. After quantitation of phosphocontent by autoradiography $\left({ }^{32} P\right.$ $A U T O R A D)$, the same membrane was probed with anti-NHE-3 antiserum 1568 to quantitate immunoreactive NHE-3 (IMMUNOBLOT). Three independent experiments showed similar results. phosphorylation status in intact cells. The in vivo data do not distinguish whether NHE-3 is a direct substrate for PKA in vivo, whether NHE-3 is phosphorylated via activation of other kinases downstream from PKA, or both.

Increase in NHE-3 phosphocontent paralleled inhibition of NHE-3 activity with application of cAMP. This is suggestive, but by itself does not sustain the conclusion that phosphorylation is the sole and direct cause for inhibition. One sees a clearcut situation in the $\alpha$ subunit of Na-K-ATPase where mutation of the highly conserved PKA-phosphorylated serine residue seemed to entirely abate functional regulation of pump activity by PKA (51). In other instances, the situation is more complex. Although serum induces acute phosphorylation of NHE-1 (54, 55), the identities of the phosphorylated residues are still unknown. Cytoplasmic deletion from amino acid 635 onwards in NHE-1 removed all major growth factor-induced phosphorylation sites but only led to a partial reduction of growth factor response (44). Conversely, internal deletion of amino acids 567-635 appeared to abolish growth factor regulation but did not affect phosphopeptide patterns (56). Point mutation of two PKA consensus sites in $\beta$ NHE only partially abrogated PKA sensitivity, while total PKA insensitivity was achieved with a further internal deletion of a cytoplasmic fragment (48). When all 10 PKA consensus sites of CFTR were empirically pointmutated, PKA regulation remained intact (57). Total abolition of PKA stimulation of CFTR $\mathrm{Cl}$ channel activity was accomplished in a quadruple mutant of the four in vivo PKA sites of CFTR using a combination of point mutations and internal deletions (58).

We speculate that acute PKA regulation of NHE-3 will likely require intact PKA consensus sites as well as other regulatory regions of NHE-3. Weinman et al. $(59,60)$ had purified a 42-55-kD phosphoprotein from renal cortical brush border membranes and postulated that it is a cofactor for PKA regulation of brush border $\mathrm{Na} / \mathrm{H}$ exchanger activity. When renal corti- 
cal apical membranes were immunodepleted of this cofactor, in vitro activation of PKA no longer inhibited apical membrane NHE activity (59-61). Since our data do not prove direct phosphorylation of NHE-3 by PKA in vivo, our findings do not contradict with those of Weinman et al. (59-61). Regulation of NHE-3 by PKA may require phosphorylation of NHE-3 in addition to binding and/or phosphorylation of regulatory cofactors. Although the regulatory cofactor described by Weinman tends to have an epithelial distribution, it is possible that other related regulatory factors are present in AP-1 cells and oocytes.

\section{Acknowledgments}

The authors acknowledge the expert technical assistance of Ladonna A. Crowder. The authors wish to thank Dr. Daniel Markowich and Dr. Heini Murer for their assistance in setting up the oocyte expression system, Dr. John Orlowski and Dr. Gary Shull for the rat NHE-3 cDNA, Dr. Sergio Grinstein for the AP-1 cells, Dr. David Russell for the plasmid pCMV-5, and Dr. Robert Alpern and Dr. Michel Baum for their comments on the manuscript. The authors are grateful to Dr. Melanie Cobb for her valuable advice.

The work described was supported by the Research Service of the Department of Veterans Affairs and the National Institutes of Health (DK48482-01). Yasuyoshi Yamaji was the recipient of a National Kidney Foundation Fellowship.

\section{References}

1. Mahnensmith, R. L., and P. S. Aronson. 1985. The plasma membrane Na/ $\mathrm{H}$ exchanger and its role in physiological and pathophysiological processes. Circ. Res. 56:773-788.

2. Alpern, R. J., D. K. Stone, and F. C. Rector, Jr. 1994. Renal acidification mechanisms. In The Kidney. B. M. Brenner and F. C. Rector Jr., editors. W. B. Saunders Co., Philadelphia. 318-379.

3. Counillon, L., and J. Pouysségur. 1994. Molecular biology and hormona regulation of vertebrate $\mathrm{Na} / \mathrm{H}$ exchanger isoforms. In Molecular Biology and Function of Carrier Proteins. The Rockefeller University Press. 169-185.

4. Sardet, C., A. Franchi, and J. Pouysségur. 1989. Molecular cloning, primary structure, and expression of the human growth factor-activatable $\mathrm{Na} / \mathrm{H}$ antiporter. Cell. 56:271-280.

5. Tse, C.-M., S. A. Levine, C. H. C. Yun, M. H. Montrose, P. J. Little, J. Pouysségur, and M. Donowitz. 1993. Cloning and expression of a rabbit cDNA encoding a serum-activated ethylisopropylamiloride resistant epithelial $\mathrm{Na} / \mathrm{H}$ exchanger isoform (NHE-2). J. Biol. Chem. 268:11917-11924.

6. Wang, Z., J. Orlowski, and G. E. Shull. 1993. Primary structure and functional expression of a novel gastrointestinal isoform of the rat $\mathrm{Na} / \mathrm{H}$ exchanger. J. Biol. Chem. 268:11925-11928.

7. Orlowski, J., R. A. Kandasamy, and G. E. Shull. 1992. Molecular cloning of putative members of the $\mathrm{Na} / \mathrm{H}$ exchanger gene family. J. Biol. Chem 267:9331-9339.

8. Tse, C. M., S. R. Bryant, M. S. Walker, J. Pouysségur, and M. Donowitz 1992. Cloning and sequencing of a rabbit cDNA encoding an intestinal and kidney-specific Na/H exchanger isoform (NHE-3). J. Biol. Chem. 267:93409346.

9. Amemiya, M., Y. Yamaji, A. Cano, O. W. Moe, and R. J. Alpern. 1995 Acid incubation increases NHE-3 mRNA abundance in OKP cells. Am. J. Physiol. (Cell Physiol. 38):C126-C133.

10. Baird, N., A. Menon, Z. Wang, P. Meneton, Y. Su, J. Orlowski, and G. E Shull. 1994. Identification and cloning of a fifth member of the $\mathrm{Na} / \mathrm{H}$ exchanger gene family. J. Am. Soc. Nephrol. 5:246a. (Abstr.)

11. Orlowski, J. 1993. Heterologous expression and functional properties of amiloride high affinity (NHE-1) and low affinity (NHE-3) isoforms of the rat $\mathrm{Na} / \mathrm{H}$ exchanger. J. Biol. Chem. 268:16369-16377.

12. Tse, C.-M., S. A. Levine, C. H. C. Yun, S. R. Bryant, J. Pouysségur, M. H. Montrose, and M. Donowitz. 1993. Functional characteristics of a cloned epithelial $\mathrm{Na} / \mathrm{H}$ exchanger (NHE3): resistance to amiloride and inhibition by protein kinase C. Proc. Natl. Acad. Sci. USA. 90:9110-9114.

13. Baum, M., D. Biemesderfer, D. Gentry, and P. S. Aronson. 1995. Maturation of rabbit cortical NHE-3 and NHE-1: effect of glucocorticoids. Am. J. Physiol. (Renal Fluid Electrolyte Physiol. 37):F815-F820.
14. Baum, M., O. W. Moe, D. L. Gentry, and R. J. Alpern. 1994. Effect of glucocorticoids on renal Na/H exchangers. Am. J. Physiol. 267 (Renal Fluid Electrolyte Physiol.):F437-F442.

15. Yun, C. H., S. Gurubhagavatula, S. A. Levine, J. M. Montgomery, S. R. Brant, M. E. Cohen, J. Pouysségur, C. M. Tse, and M. Donowitz. 1993. Glucocorticoid stimulation of ileal $\mathrm{Na}$ absorptive cell brush border $\mathrm{Na} / \mathrm{H}$ exchange and association with an increase in message for NHE-3, an epithelial isoform $\mathrm{Na} / \mathrm{H}$ exchanger. J. Biol. Chem. 268:206-211.

16. Biemesderfer, D., J. Pizzonia, M. Exner, R. Reilly, P. Igarasgi, and P. S. Aronson. 1994. NHE-3: a Na/H exchanger isoform of the renal brush border. Am. J. Physiol. 265:F736-F742.

17. Amemiya, M., J. Loffing, M. Lötscher, B. Kaissling, R. J. Alpern, and O. W. Moe. 1995. NHE-3 expression in the rat renal proximal tubule and thick ascending limb. Kidney Int. In press.

18. Umemuma, S., D. Marver, D. Smyth, and W. Pettinger. 1985. $\alpha_{2}$-adrenoreceptors and cell cAMP levels in single nephron segments. Am. J. Physiol. 18:F28F33.

19. Liu, F.-Y., and M. G. Cogan. 1989. Angiotensin II stimulates early proximal bicarbonate absorption in the rat by decreasing cAMP. J. Clin. Invest. 84:8391.

20. Felder, C. C., T. Campbell, F. Albrecht, and P. A. Jose. 1990. Dopamine inhibits NHE activity in renal brush border vesicles by stimulation of adenylate cyclase. Am. J. Physiol. (Renal Fluid Electrolyte Physiol. 28):F297-F303.

21. Khan, A., G. M. Dolson, M. K. Hise, S. C. Bennett, and E. J. Weinman. 1985. Parathyroid hormone and dibutyryl cAMP inhibits $\mathrm{Na} / \mathrm{H}$ exchange in renal brush border vesicles. Am. J. Physiol. 248 (Renal Fluid Electrolyte Physiol. 17):F212-F218.

22. Weinman, E. J., S. Shenolikar, and A. M. Khan. 1987. cAMP-associated inhibition of $\mathrm{Na} / \mathrm{H}$ exchanger in rabbit kidney brush border membranes. Am. J. Physiol. 252 (Renal Fluid Electrolyte Physiol. 21):F19-F25.

23. Pollock, A. S., D. G. Warnock, and G. J. Strewler. 1986. Parathyroid hormone inhibition of $\mathrm{Na} / \mathrm{H}$ antiporter activity in a cultured renal cell line. Am. J. Physiol. 250 (Renal Fluid Electrolyte Physiol. 19):F217-F225.

24. Casavola, V., C. Helmle-Kolb, and H. Murer. 1989. Separate regulatory control of apical and basolateral $\mathrm{Na} / \mathrm{H}$ exchange in renal epithelial cells. Biochem. Biophys. Res. Commun. 165:833-837.

25. Cano, A., P. A. Preisig, and R. J. Alpern. 1993. Cyclic adenosine monophosphate acutely inhibits and chronically stimulates $\mathrm{Na} / \mathrm{H}$ antiporter in OKP cells. J. Clin. Invest. 92:1632-1638.

26. Rotin, D., and S. Grinstein. 1985. Impaired cell volume regulation in $\mathrm{Na} /$ H exchanger deficient mutants. Am. J. Physiol. 257 (Cell Physiol. 26):C1158 C1165.

27. Sambrook, J., E. F. Fritsch, and T. Maniatis. 1989. Molecular Cloning A Laboratory Manual. Cold Spring Harbor Laboratory, Cold Spring Harbor, NY

28. Franchi, A., D. Perruca-Lostanlen, and J. Pouysségur. 1986. Functional expression of a human $\mathrm{Na} / \mathrm{H}$ antiporter gene transfected into antiporter-deficient mouse L cells. Proc. Natl. Acad. Sci. USA. 83:9388-9392.

29. Moe, O. W., R. T. Miller, S. Horie, A. Cano, P. A. Preisig, and R. J. Alpern. 1991. Differential regulation of $\mathrm{Na} / \mathrm{H}$ antiporter by acid in renal epithelial cells and fibroblasts. J. Clin. Invest. 88:1703-1708.

30. Boyle, W. J., P. Van der Veer, and T. Hunter. 1991. Phosphopeptide mapping and phosphoamino acid analysis by 2-dimensional separation on thinlayer cellulose plates. Methods Enzymol. 201:110-149.

31. Pearson, R. B., and B. E. Kemp. 1991. Protein kinase phosphorylation site sequences and consensus specificity motifs. Methods Enzymol. 200:62-84.

32. Chan, Y. L. 1980. Adrenergic control of bicarbonate absorption in the proximal convoluted tubule of the rat kidney. Pfiugers Arch. 388:159-164.

33. Weinman, E. J., S. C. Samson, T. F. Knight, and H. O. Senekjian. 1982 Alpha and beta adrenergic agonists stimulate water absorption in the rat proximal tubule. J. Membr. Biol. 69:107-111.

34. Nord, E. P., M. J. Howard, A. Hafezi, P. Moradeshagi, S. Vaystub, and P. A. Insel. 1987. Alpha-2 adrenergic agonists stimulate $\mathrm{Na} / \mathrm{H}$ antiport activity in the rabbit renal proximal tubule. J. Clin. Invest. 80:1755-1762.

35. McKinney, T. D., and P. Myers. 1985. Bicarbonate transport by proximal tubule: effect of PTH and dibutyryl cAMP. Am. J. Physiol. 238 (Renal Electrolyte Physiol. 7):F166-F179.

36. Bello-Reuss, E., Y. Hogashi, and Y. Kaneda. 1983. Dopamine decreases fluid absorption in rabbit proximal tubule. Miner. Electrolyte Metab. 9:147-150.

37. Schuster, V. L., J. P. Kokko, and H. R. Jacobson. 1984. Angiotensin II directly stimulates sodium transport in rabbit proximal convoluted tubules. $J$. Clin. Invest. 73:507-515.

38. Liu, F.-Y., and M. G. Cogan. 1987. Angiotensin II: a potent regulator of acidification in the rat early proximal tubule. J. Clin. Invest. 80:272-275.

39. Saccomani, G., K. D. Mitchell, and G. Navar. 1990. Angiotensin II stimulation of Na/H exchange in proximal tubule. Am. J. Physiol. 258:F1188-F1195.

40. Eiam-Ong, S., S. A. Hilden, A. J. King, C. A. Johns, and N. E. Madias. 1992. Endothelin-1 stimulates the $\mathrm{Na} / \mathrm{H}$ antiporter and $\mathrm{Na} / \mathrm{HCO}_{3}$ transporter in rabbit renal cortex. Kidney Int. 42:18-24. 
41. Guntupalli, J., and T. D. Dubose, Jr. 1994. Effects of endothelin on rat renal proximal tubule $\mathrm{NaP}$ cotransport and Na/H exchange. Am. J. Physiol. 266 (Renal Electrolyte Physiol. 35):F658-F666.

42. Felder, C. C., F. Albrecht, G. M. Eisner, and P. A. Jose. 1990. The signal transducer for DA-1 regulated sodium transport in renal cortical brush border membrane vesicles. Am. J. Hypertens. 3:475-505.

43. Levine, S. A., M. M. Montrose, C. M. Tse, and M. Donowitz. 1993 Kinetics and regulation of three cloned mammalian $\mathrm{Na} / \mathrm{H}$ exchangers stably expressed in a fibroblast cell line. J. Biol. Chem. 268:25527-25535.

44. Wakabayashi, S., P. Farfournoux, C. Sardet, and J. Pouysségur. 1992. The $\mathrm{Na} / \mathrm{H}$ antiporter cytoplasmic domain mediates growth factor signals and controls H-sensing. Proc. Natl. Acad. Sci. USA. 89:2424-2428.

45. Winkel, G. K., C. Sardet, J. Pouysségur, and H. E. Ives. 1993. Role of cytoplasmic domain of the $\mathrm{Na} / \mathrm{H}$ exchanger in hormonal activation. J. Biol. Chem $268: 3396-3400$

46. Borgese, F., C. Sardet, M. Cappadoro, J. Pouysségur, and R. Motais. 1992 Cloning and expression of a cAMP-activated $\mathrm{Na} / \mathrm{H}$ exchanger: evidence that the cytoplasmic domain mediates hormonal regulation. Proc. Natl. Acad. Sci. USA 89:6765-6769.

47. Guizouarn, H., F. Borgese, B. Pellissier, F. Garcia-Romeu, and R. Motais 1993. Role of protein phosphorylation and dephosphorylation in activation and desensitization of the cAMP-dependent Na/H antiport. J. Biol. Chem. 268:86928699.

48. Borgese, F., M. Malapert, B. Fievet, J. Pouysségur, and R. Motais. 1994 The cytoplasmic domain of the $\mathrm{Na} / \mathrm{H}$ exchangers dictates the nature of the hormonal response: behavior of a chimeric human NHE-1/trout $\beta$-NHE antiporter. Proc. Natl. Acad. Sci. USA. 91:5431-5435.

49. Bertorello, A. M., A. Aperia, S. I. Walaas, A. C. Nairn, and P. Greengard 1991. Phosphorylation of the catalytic subunit of Na-K-ATPase inhibits the activity of the enzyme. Proc. Natl. Acad. Sci. USA. 88:11359-11362.

50. Beguin, P., A. T. Beggah, A. V. Chibalin, P. Burgener-Kairuz, F. Jaisser P. M. Mathews, B. C. Rossier, S. Cotecchia, and K. Geering. 1994. Phosphorylation of the Na-K-ATPase $\alpha$-subunit by protein kinase $\mathrm{A}$ and $\mathrm{C}$ in vitro and in intact cells. J. Biol. Chem. 269:24437-24445.

51. Fisone, G., S. X.-J. Chang, A. C. Nairn, A. J. Czernik, H. C. Hennings, Jr., J.-O. Höög, A. M. Bertorello, R. Kaiser, T. Bergman, H. Jornvall, et al. 1994.
Identification of the phosphorylation site of cAMP-dependent protein kinase on Na-K-ATPase and effect of site-directed mutagenesis. J. Biol. Chem. 269:93689373

52. Lawrence, J. C., Jr., J. F. Hiken, and D. E. James. 1990. Phosphorylation of the glucose transporter in rat adipocytes: identification of the intracellular domain at the carboxy terminus as a target for phosphorylation in intact cells and in vitro. J. Biol. Chem. 265:2324-2332.

53. Picciotto, M. R., J. A. Cohn, G. Bertuzzi, P. Greengard, and A. C. Nairn. 1992. Phosphorylation of the cystic fibrosis transmembrane conductance regulator. J. Biol. Chem. 267:12742-12752.

54. Sardet, C., L. Counillon, A. Franchi, and J. Pouysségur. 1990. Growth factors induce phosphorylation of the $\mathrm{Na} / \mathrm{H}$ antiporter, a glycoprotein of $110 \mathrm{kD}$ Science (Wash. DC). 247:723-742.

55. Sardet, C., P. Farfournoux, and J. Pouysségur. 1991. $\alpha$-Thrombin, epidermal growth factor, and okadaic acid activate the Na/H exchanger, NHE-1 by phosphorylating a set of common sites. J. Biol. Chem. 266:19166-19171.

56. Wakabayashi, S., B. Bertrand, M. Shigekawa, P. Farfournoux, and J. Pouysségur. 1994. Growth factor activation and $\mathrm{H}$-sensing of the $\mathrm{Na} / \mathrm{H}$ exchange isoform NHE-1: evidence in favor of a regulatory accessory factor. J. Biol. Chem. 269:5583-5588.

57. Chang, X.-B., J. A. Tabcharani, Y.-X. Hou., T. J. Jensen, N. Kartner, N. Alon, J. W. Hanrahan, and J. R. Riordan. 1993. Protein kinase A still activates CFTR chloride channel after mutagenesis of all 10 PKA consensus phosphorylation sites. J. Biol. Chem. 268:11304-11311.

58. Cheng, S. H., D. P. Rich, J. Marshall, R. J. Gregory, M. J. Welsh, and A. E. Smith. 1991. Phosphorylation of the R domain by cAMP-dependent protein kinase regulates the CFTR chloride channel. Cell. 66:1027-1036.

59. Morell, G., D. Steplock, S. Shenolikar, and E. J. Weinman. 1990. Identification of a putative $\mathrm{Na} / \mathrm{H}$ exchanger regulatory cofactor in rabbit renal BBM. Am. J. Physiol. 259 (Renal Fluid Electrolyte Physiol. 28):F867-F871.

60. Weinman, E. J., D. Steplock, G. Bui, N. Yuan, and S. Shenolikar. 1990 Regulation of renal Na-H exchanger by cAMP-dependent protein kinase. Am. $J$. Physiol. 258 (Renal Fluid Electrolyte Physiol. 27):F1254-F1258.

61. Weinman, E. J., D. Steplock, and S. Shenolikar. 1993. cAMP-mediated inhibition of the renal brush border membrane $\mathrm{Na}+-\mathrm{H}+$ exchanger requires a dissociable phosphoprotein cofactor. J. Clin. Invest. 92:1781-1786. 